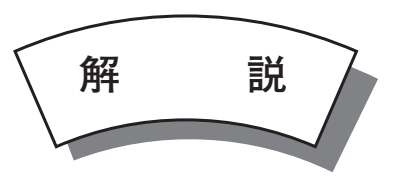

\title{
高温プロセスにおけるダイオキシン類発生に関する研究動向
}

\section{Recent Research Trends on the Dioxin Emissions in High Temperature Process}

\section{葛西栄輝* \\ Eiki KASAI}

Key Words: dioxin emissions, recycle process, metal, POPs, precursor

\section{1.はじめに}

我が国におけるダイオキシン類污染への一般の関心は 1996〜 7 年頃に一気に高まる。もちろんそれ以前から、「ダ イオキシン」はベトナム戦争で使用された枯葉剤（主に2, 4, 5-T: 2, 4, 5-trichlorophenoxy acetic acid）に含まれる不純物、 あるいは塩化ビニル等の焼却によって発生する毒物として 知られる存在ではあった。しかし、この頃、大阪府能美美 化センターの一般廃棄物焼却施設周辺土壤の高濃度污染の 発覚や、産業廃妄物焼却施設が集中する埼玉県所沢市など の農作物污染などが頻繁かつセンセーショナルにマスコミ に取り上げられたため、極めて身近な問題と認識されるよ うになったのである。

これにより、国や自治体の排出削減への取り組みが本格 化する。まず、当時環境へのダイオキシン類の毒性排出の 中で極めて大きな割合を占めていた一般廃棄物焼却施設以 外にも、産業廃棄物焼却炉や製鋼用電気炉への排出ガス濃 度の上限目標值が示され、1999 年 6 月には中央環境審議会 から、人が生涯にわたって摂取しても健康影響が現れない 指標である耐容一日摂取量（TDI: Tolerable Daily Intake）と して $4 \mathrm{pg}-\mathrm{TEQ} /(\mathrm{kg} \cdot \mathrm{d})$ の值が答申された。（TEQ*: Toxicity Equivalent Quantity（毒性等価量））このような過程で中で、 世界に類を見ないと言われるダイオキシン類に特化した法 律「ダイオキシン類対策特別措置法」が 1999 年 7 月に成立 し、2000 年 1 月に施行された。

特別措置法施行から既に 8 年が経過しようとしているが、 最近の産業活動に係るダイオキシン類の毒性排出量の変化 をTable 1 に示す。この間、我が国全体の排出量は 1997 年 の $8 \mathrm{~kg}$-TEQ から 2005 年の $336 \mathrm{~g}$-TEQ へと $1 / 20$ 以下に激 減した。また、毒性排出量全体の $60 \%$ を占めていた一般廃 棄物焼却施設からの排出量は $20 \%$ 以下となり、産業廃棄物 を入れた廃棄物焼却施設の合計も全体の $65 \%$ 程度の割合ま で減少している。大気への排出規制を受ける廃棄物焼却以
外の特定施設としては、製鋼用電気炉、亜鉛回収プロセス、 アルミニウム合金製造、鉄鉱石焼結プロセスがある。前者 3つは、それぞれ、鉄鋼スクラップから鉄鋼を、製鋼用電 気炉ダストから亜鉛を、アルミニウムスクラップからアル ミニウム合金を回収・製造する金属素材のリサイクルプロ セスである。鉄鉱石焼結プロセスは直接的なリサイクルプ ロセスではないが、製鉄所内で発生する多量のダスト、ス ケール、スラッジなどかなりの量のリサイクル原料を取り 扱っている。Table 1は、このような金属の高温リサイク ル過程からのダイオキシン類発生量も顕著に低下している ことを示しており、関連企業の研究開発努力が伺われる。

以上のような結果から、我が国のダイオキシン類対策は 極めて効果的に進んできたという評価がある一方、焼却炉 の大規模化や最新の排ガス処理設備設置など、巨額な対策 費用支出への批判もある。2002 年に厚生省は、福岡県を中 心として 1968 年に発生したカネミ油症の原因物質が、混 入したPCBs (polychlorinated biphenyls) そのものではなく、 それに不純物として含まれていたダイオキシン類の一種で ある PCDFs (polychlorinated dibenzofurans) および co-PCBs (co-planar polychlorinated biphenyls) である可能性が強いこ とを認めた。ダイオキシン類を多量に摂取すれば人体へ影 響を及ぼすことは明らかであるが、一部には人間活動から 非意図的に排出されるダイオキシン類が人体に与える影響 は現状ではあまり大きくなく、我が国の排出基準は厳しす ぎるという意見も存在する ${ }^{1)}$ 。他方、2004 年 5 月には環境 中での残留性が高いダイオキシン類や PCB を含む 12 物質 の環境排出削減や使用廃絶に向けた「残留性有機污染物質 に関するストックホルム条約（通称 POPs（persistent organic pollutants）条約）」が発効し、批准国である我が国でも非 意図的排出量削減に向けた総合的な対策が進められつつあ る。

本稿は上記議論の是非等に踏み込むものではないが、大 気環境へのダイオキシン類排出の主な原因である廃棄物焼

*東北大学多元物質科学研究所（干 980-8577 仙台市青葉区片平 2-1-1）

Institute of Multidisciplinary Research for Advanced Materials, Tohoku University (2-1-1 Katahira, Aoba-ku, Sendai 980-8577 Japan) 
Table 1. Inventory for major dioxin sources of environmental releases in Japan from 1997 to 2005, compiled by the Ministry of Environment. g-TEQ/yWHO-TEF (1998)

\begin{tabular}{lccccccccc}
\hline Emission source & 1997 & 1998 & 1999 & 2000 & 2001 & 2002 & 2003 & 2004 & 2005 \\
\hline Municipal W.I. & 5000 & 1550 & 1350 & 1019 & 812 & 370 & 71 & 64 & 62 \\
Industrial W.I. & 1500 & 1100 & 690 & 555 & 533 & 265 & 74 & 69 & 73 \\
Small-scale W.I. & 927 & 927 & 683 & 610 & 398 & 124 & 86 & 88 & 85 \\
EAF for steelmaking & 228.5 & 139.9 & 141.5 & 131.1 & 95.3 & 94.8 & 80.3 & 64.0 & 49.6 \\
Iron ore sintering & 135.0 & 113.8 & 101.3 & 69.8 & 65.0 & 51.1 & 35.7 & 30.4 & 29.3 \\
Zinc recovery & 47.4 & 25.4 & 21.8 & 26.5 & 9.2 & 14.7 & 5.5 & 8.1 & 4.1 \\
Aluminum alloy making & 21.3 & 19.4 & 13.6 & 12.8 & 15.0 & 14.4 & 14.9 & 10.2 & 13.1 \\
Cement making & 4.7 & 4.1 & 3.9 & 4.0 & 3.2 & 3.7 & 4.7 & 4.7 & 4.3 \\
Copper making & 4.9 & 4.9 & 0.5 & 0.6 & 0.3 & 0.5 & 0.6 & 0.4 & 0.6 \\
Copper processing & 3.2 & 3.2 & 1.2 & 1.3 & 1.3 & 1.3 & 1.4 & 1.5 & 1.7 \\
Power plant & 1.6 & 1.6 & 1.6 & 1.7 & 1.6 & 1.9 & 2.0 & 2.0 & 2.2 \\
Crematories & $2.1-4.6$ & $2.2-4.8$ & $2.2-4.9$ & $2.2-4.8$ & $2.2-4.9$ & $2.3-5.1$ & $2.3-5.1$ & $2.4-5.3$ & $2.4-5.3$ \\
Automobile W.G. & 1.4 & 1.4 & 1.4 & 1.4 & 1.4 & 1.4 & 1.4 & 1.3 & 1.2 \\
& & & & & & & & & \\
Industrial W.I. & 5.3 & 5.3 & 5.3 & 2.5 & 1.5 & 0.86 & 0.60 & 0.65 & 0.36 \\
Caprolactam making & 2.5 & 2.5 & 2.5 & 1.8 & 0.07 & 0.11 & 0.11 & 0.08 & 0.04 \\
Acethylene making & 1.8 & 1.6 & 1.6 & 1.8 & 0.02 & 0.02 & 0.02 & 0.01 & 0.00 \\
Pulp bleaching & 0.74 & 0.71 & 0.74 & 0.73 & 0.90 & 0.65 & 0.46 & 0.62 & 0.58 \\
vinyl chloride making & 0.54 & 0.53 & 0.55 & 0.20 & 0.58 & 0.16 & 0.10 & 0.07 & 0.10 \\
Sewerage treatment & 1.1 & 1.1 & 1.1 & 1.1 & 0.99 & 0.51 & 0.54 & 0.36 & 0.46 \\
Solid Waste landfill site & 0.09 & 0.09 & 0.09 & 0.056 & 0.027 & 0.021 & 0.020 & 0.018 & 0.012 \\
\hline \multicolumn{1}{c}{ Total } & 7910 & 3920 & 3040 & 2460 & 1960 & 957 & 386 & 352 & 336 \\
(To water) & 12.8 & 12.3 & 12.4 & 8.6 & 4.6 & 2.6 & 2.1 & 2.0 & 1.8 \\
\hline
\end{tabular}

却や金属リサイクルなどの高温プロセス内で進行するダイ オキシン類の生成と分解挙動に関する研究と、鉄鋼関連プ ロセスに関する排出抑制技術の動向についてまとめ、情報 提供をはかりたい。

\section{2. ダイオキシン類特別措置法}

ダイオキシン類特別措置法では、TDIを「4 pg-TEQ/ $(\mathrm{kg} \cdot \mathrm{d})$ 以下で政令が定める值」とし、大気、水質、土壤の それぞれについて環境基準を定めるものとされている。ま た、ダイオキシン類に PCDDs (polychlorinated dibenzo-pdioxins) と PCDFs の他に co-PCBs を含めること、ダイオキ シン類を排出する特定施設に対し排出基準を定めること、 施設設置者による測定とデータの公開義務、污染土壤対策 などについても記されている。関連政令においては、TDI を $4 \mathrm{pg}-\mathrm{TEQ} /(\mathrm{kg} \cdot \mathrm{d})$ と定め、大気 $0.6 \mathrm{pg}-\mathrm{TEQ} / \mathrm{m}^{3}$ 、水質 1 pg-TEQ/L、土壤 $1000 \mathrm{pg}$-TEQ/g-dry の環境基準が示されて いる。さらに、2002 年には底質（河川、湖沼、海洋などの 水底に堆積している土や泥）に対して、150 pg-TEQ/g-dry が定められた。

さらに、このような環境基準を達成するために、排ガス や排水に排出基準を定める特定施設を指定した。排ガスに 対するダイオキシン類濃度基準が定められたのは前述した 廃棄物焼却炉を含む 5 つ施設である。焼却炉は施設規模 によって 3 つに分類され、それぞれ異なる排出基準が定め られている。排ガス量の多い $4 \mathrm{Mg} / \mathrm{h}$ 以上の処理能力をも つ焼却炉と鉄鉱石焼結プロセスには、共に新設の場合で 0.1 $\mathrm{ng}-\mathrm{TEQ} / \mathrm{m}^{3}$ (STP) という最も厳しい基準值が適用されてい
る（Table 2)。なお、これらは、環境対策が進んでいると される $\mathrm{EU}$ 諸国とほぼ同一の基準である。

\section{3. ダイオキシン類の生成および分解過程}

廃棄物焼却炉や金属のリサイクルプロセスの排ガス中に 一定のダイオキシン類が含まれる背景としては、廃呆物や リサイクル原料中に十分な濃度の炭素および塩素源が混在 していること、およびダイオキシン類の基本構造（benzene 骨格）を持つ分子の生成反応とその塩素化を促進する可能 性のある金属成分も相当量含まれていることが挙げられ る。上述した各プロセス反応系では代表的な温度パターン や雲囲気条件がそれぞれ異なるものの、ダイオキシン類の 主たる生成ルートとしては従来、1）前駆物質 (precursor) か らの生成反応、2） de novo 合成反応、3）高分子化合物の熱 分解反応の 3 つに分類されてきた。

1）前駆物質からの生成反応

ダイオキシン類の構造の一部、主に benzene 骨格を有す る単環芳香族化合物からの生成を指しす場合が多く、比較 的低温の農薬等の化学製品製造やパルプ漂白工程などでの 主要生成ルートとされる。典型的な例としては、Fig. 1 に 示す 2, 4, 5-TCP (tetrachlorophenol) の縮合反応による 2, 3, 7, 8-TCDD (tetrachloro-dibenzo- $p$-dioxins) の生成がある ${ }^{14)} 。$ 前 駆物質を広義に解釈し、比較的小さな構造を持つ脂肪族化 合物類など benzene 骨格を持たない化合物も前駆物質の範 囲に含めている場合もある。もっとも、メタン、エタンな ど炭化水素の熱分解により生成する非晶質炭素粒子（すす） 
の基本構造も benzene 骨格であり、脂肪族化合物類が直接 的な前駆物質であるかどうかの検証は難しい。

Fig. 1 から分かるように、前駆物質の種類が一定であれ ば、その塩素や水酸基の化合位置で生成するダイオキシン 類の構造が決まってくる。よって、前駆物質から生成する ダイオキシン類の異性体パターンは、特定の異性体が多い 特徵的な形状を示す。前駆物質からのダイオキシン類の生 成は、主に触媒性を有する固体表面の不均一反応によると 考えられてきた。高温プロセスでは、炉や煙道内壁、それ

Table 2. Emission standards of dioxins on the specific facilities to the air (ng-TEQ/m3(STP))

\begin{tabular}{cccc}
\hline Specific facility & Capacity & Newfadility & Existingfacility* \\
\hline Waste incinerator & $>4 \mathrm{M} \mathrm{g/h}$ & 0.1 & 1 \\
\cline { 2 - 4 } $\begin{array}{c}\text { (A rea of grate or hearth }>0.5 \mathrm{~m} / \\
\text { or Incineration capacity }>50 \mathrm{~kg} / \mathrm{h} \text { ) }\end{array}$ & $2 \sim 4 \mathrm{M} \mathrm{g/h}$ & 1 & 5 \\
\cline { 2 - 4 } & $<2 \mathrm{M} \mathrm{g/h}$ & 5 & 10 \\
\hline EAF (electric arc furnace) for steel making & 0.5 & 5 \\
\hline Iron ore sintering process & 0.1 & 1 \\
\hline Zinc recovery process from EAF dust & 1 & 10 \\
\hline A luminum alloy making from aluminum scrap & 1 & 5 \\
\hline
\end{tabular}

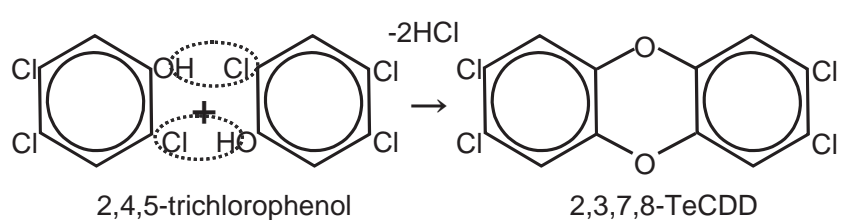

Fig. 1. Formation of 2,3,7,8-TeCDD from 2,4,5-TCP as a precursor.
に付着した種々の物質、燃焼ガスに含まれる飛灰など、様々 な固相や粒子表面が反応サイトを提供する可能性がある。 一方で、最近は均一反応による生成経路の提案もなされて おり 2) (Fig. 2)、詳しい解析が進められている。

2) de novo 合成反応

$\lceil$ de novo」には、「新たな…新規に…といった意味が あり、従来、前駆物質からの生成との対比として、ダイオ キシン類の化学構造と直接的に関連しない炭素や炭化水素 から熱反応により生成する反応経路全般のことを指して使 われてきた。一般的には燃焼ガスに含まれる未燃炭素系残 椬「すす」からのダイオキシン類生成を指す場合が多い。 この場合、ダイオキシン類生成が顕著とされる温度域は $200 \sim 500^{\circ} \mathrm{C}$ であり、通常は炭材粒子の燃焼が継続できる 条件ではない。しかし、酸素が共存すれば表面において緩 やかな酸化反応は進行可能であり、このような不完全な酸 化反応 (部分酸化反応) に伴ってダイオキシン類を含む様々 な有機化合物が生成するものと考えられる。de novo 合成 反応により生成するダイオキシン類の異性体パターンは、 特定の前駆物質から生成するケースとは異なり、一様な分 布パターンを示す場合が多く、焼却パターン（incineration profile）と呼ばれる。鉄鉱石焼結プロセスや製鋼用電気炉 の排ガスも焼却パターンに類似した特長を持つ。

\section{3）高分子化合物の熱分解反応}

複数の benzene 骨格から形成される比較的高分子の化合 物が熱作用により部分開裂してダイオキシン類が生成する 反応であり、広義には de novo 合成反応にも含めることが できる。このような反応の一例を Fig. 3 に示す。フェニル プロパン単位が不規則に結合したリグニンなどからのダイ オキシン類生成において詳細な検討が続けられている反応

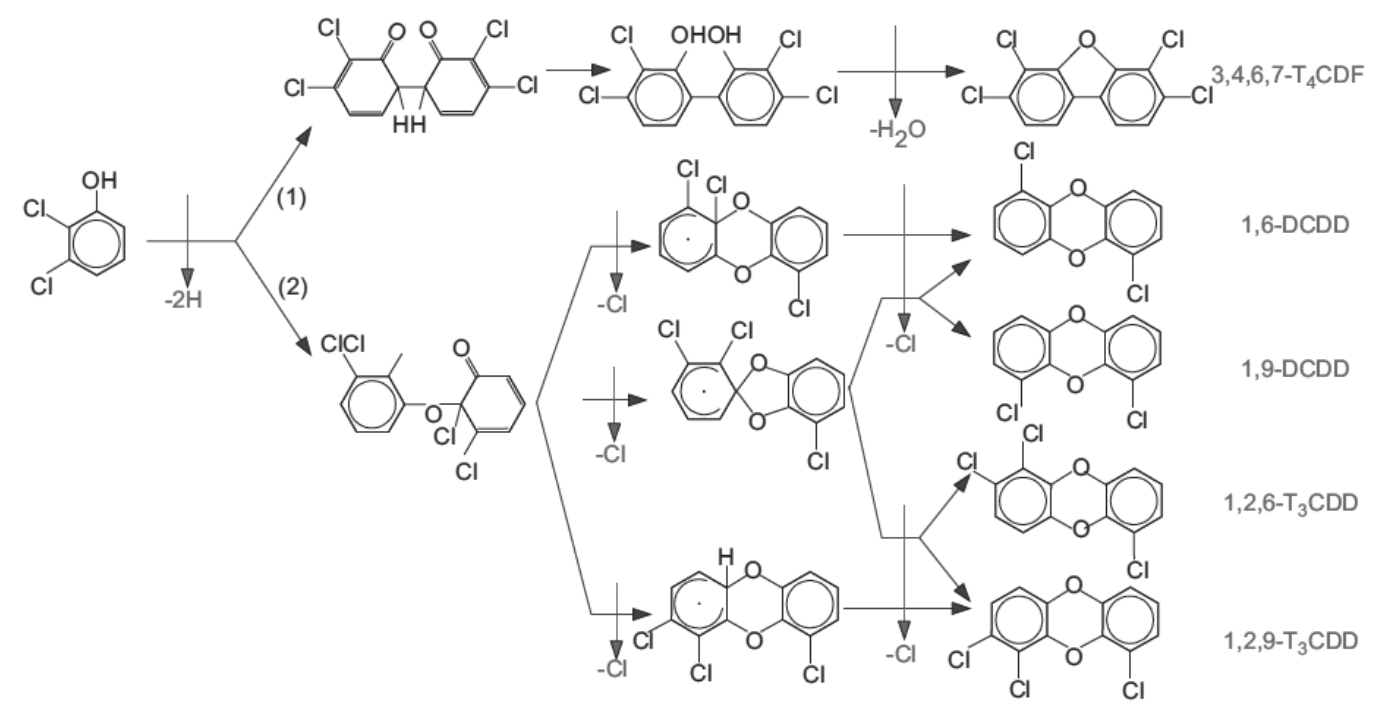

Fig. 2. Homogeneous precursor reactions for the formation of PCDD and PCDF from 2,3-dichlorophenol ${ }^{2)}$. 
(a)
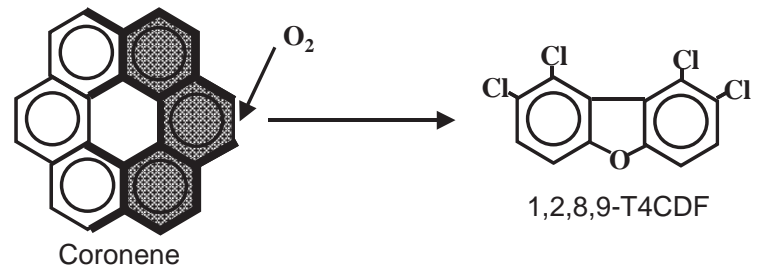

1,2,8,9-T4CDF

(b)

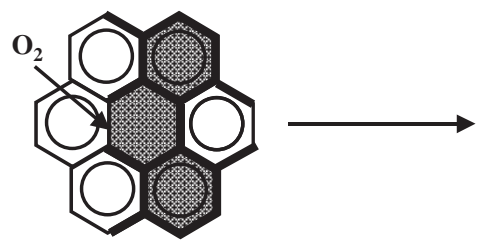

Coronene

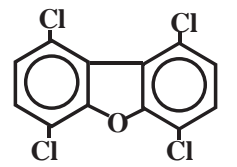

1,4,6,9-T4CDF

Fig. 3. Illustration of TeCDFformation from coronene. (a) Incorporation of oxygen occurs from outside of coronenemolecule to result in 1,2,8,9-T4CDF, and (b) from the inside form 1,4,6.9- $\mathrm{TeCDF}^{3)}$.

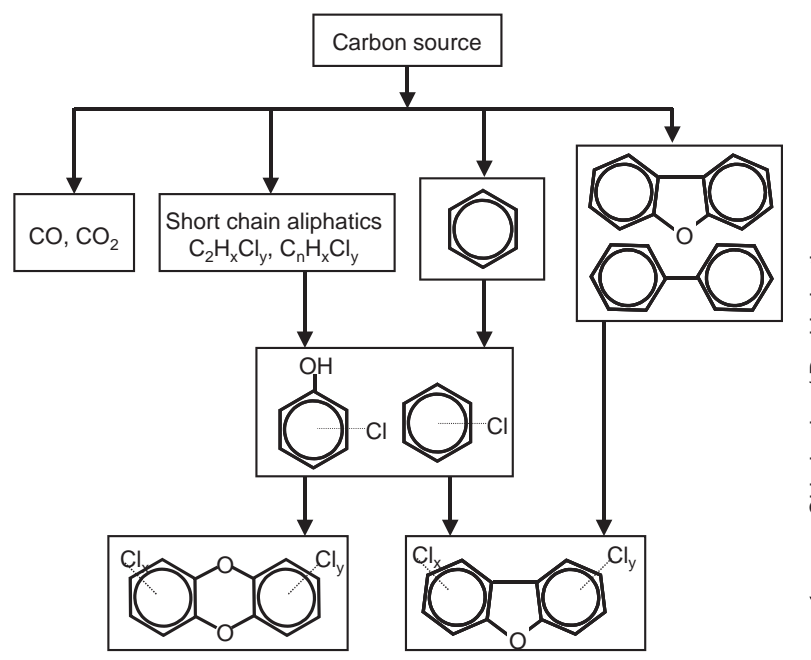

Fig. 4. A schematic drawing of the de novosynthesis of dioxins. All steps indicated are surface-induced reactions that are catalyzed by the presence of metallic components, e.g., copper and iron ${ }^{5)}$.

\section{機構である ${ }^{4)}$ 。}

以上は、主に発生するプロセスの雲囲気や温度条件など から便宜的に用いられてきた分類であるが、これまでの研 究により反応経路の詳細が明らかになるにつれ、統一的な 説明が試みられるようになってきた。つまり、炭素源の部 分酸化 (de novo 合成) 反応よって生成したクロロベンゼン、 クロロフェノール、ビフェニルなどが前駆物質となりダイ オキシン類が生成するルートである ${ }^{5)}$ (Fig. 4)。このよう な生成ルートにおける炭素源は、主に炭素のマク口構造を 持つ「すす」やチャーであり、実験試料としてはグラファ イトや焼却飛灰中の残留炭素に加え、活性炭、石炭、褐炭 (lignite)、木炭などが試料として用いられてきた ${ }^{67)}$ 。「すす」

のように非結晶性でマクロ構造内部に欠陥や結合酸素を多 く持つものが、グラファイトのように不純物が少なく規則 正しい構造を持つ炭材に比較して、ダイオキシン類の生成 速度が大きいことが指摘されている ${ }^{5}$ 。しかし、温度や雾 囲気が同一の条件で比較すると、[炭材の部分酸化量］：[ダ イオキシン類生成量］の比は炭材によらずほぼ一定である ことが実験的に確かめられており ${ }^{8)}$ 、単純に欠陥や結合酸 素を多く持つ炭素の部分酸化反応速度が大きいことでも説 明可能である。

一般的な燃焼条件においてダイオキシン類は熱力学的に 不安定であり、大量に生成するものではない。このことは 一旦生成したダイオキシン類については分解の方向への駆 動力が大きいことを意味する。したがって、ダイオキシン 類の生成メカニズムを定量的に考える場合、同時に分解反 応についての考慮が常に必要となる。de novo 合成反応に関 する Altwickerの先駆的研究 ${ }^{9}$ では、雾囲気中の酸素濃度 が $5 \sim 10 \%$ 程度の条件において、保持温度 $300^{\circ} \mathrm{C}$ 付近で最 も多くのダイオキシン類が生成する報告されている。一般 的には、この温度域が現在でもダイオキシン類生成が最も 進行する条件として知られている。しかし、その後の報告 では、 $350 \sim 400^{\circ} \mathrm{C}$ が生成反応のピーク指摘する報告が多 ( ${ }^{10-12)}$ 。この理由は、Altwickerの実験では、酸素䨌囲気下 で一定時間加熱した未燃炭素成分を含む飛灰試料に含有さ れているダイオキシン類を抽出、定量しており、揮発によ るガス相への離脱を考慮していないことによる。つまり、 温度が $300^{\circ} \mathrm{C}$ を越えると生成したダイオキシン類は炭材表 面に留まらずに揮発し、ガスと共に系外に排出されやすく なる。排出されたガス中のダイオキシン類量に対する試料 保持温度の影響についての報告值をまとめて Fig. 5 に示 す ${ }^{13)}$ 。これらのデータは、䨌囲気ガス中にダイオキシン類 の前駆物質であるクロロフェノールを加えたケースである が、相対的な生成ピークは、約 $400^{\circ} \mathrm{C}$ 程度である。

したがって、固相に残留したダイオキシン類と排出ガス と共に排出されたダイオキシン類では、ピーク温度差が存 在することになる（Fig. 6）。また、 $350^{\circ} \mathrm{C}$ 付近でダイオキ シン類生成速度のピークが現れる理由は以下のように考え られる。低温側での生成速度の増加は、温度上昇に伴う 炭材の部分酸化反応速度の増加に対応している。これと共 にダイオキシン類やその前駆物質を含む各種有機化合物全 体のの生成量も増加すると考えられるが、一方では、その 酸化分解反応速度も温度上昇に伴って指数関数的に増加す る。よって、高温側では生成したダイオキシン類自身に加 え、前駆物質の分解速度が極めて大きくなり、ダイオキシ ン類の見かけの生成量が減少するものと推定できる。

一般的に、廃衰物燃焼排ガスに含まれる塩素化芳香族化 合物の存在量は、クロロベンゼン >=クロロフェノール >> クロロナフタレン > PCBs, PCDFs > PCDDs と報告されてい る。また、塩素化炭化水素類の総濃度は数 $100 \mu \mathrm{g} / \mathrm{m}^{3}$ 以上 


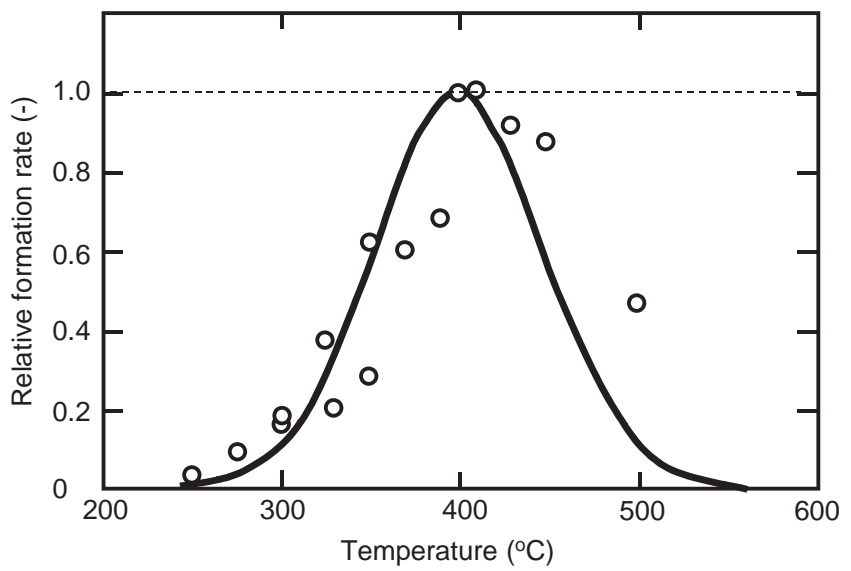

Fig. 5. Relative formation rate of dioxins in the case formed from 700 $\mathrm{mg} / \mathrm{L}$ of chlorophenol $^{13)}$.

にもなり、前駆物質であるクロロフェノールでも $150 \mu \mathrm{g} /$ $\mathrm{m}^{3}$ とダイオキシン類の 100 倍程度に達する場合もある。有 機物の然焼プロセスにおけるダイオキシン類のマクロ的な 生成経路モデル例を Fig. 7 に示す ${ }^{14)}$ 。

\section{4. ダイオキシン類の発生を促進あるいは抑制する物質}

現在の廃棄物焼却炉など、 $900^{\circ} \mathrm{C}$ を超えるような高温燃焼 条件下では、無機塩類も有機塩素化合物と同様にダイオキ シン類の塩素源となることが広く認識されている。製鋼用 電気炉や鉄鉱石焼結プロセスを考えた場合、局所あるいは 瞬間的な温度は $1300^{\circ} \mathrm{C}$ 超えるため、例えば原料に混入し た塩化ビニルや潤滑オイル中の塩素だけでなく、 $\mathrm{KCl}, \mathrm{NaCl}$, $\mathrm{CaCl}_{2}$ などの無機塩もダイオキシン類を構成する塩素とな り得る。上記鉄鋼関連プロセスを含む高温プロセスでは、 最終的にはいずれの塩素源も例えば $\mathrm{CuCl} 、 \mathrm{CuCl}_{2} 、 \mathrm{PbCl}_{2}$ な どの遷移金属の塩化物（あるいは酸塩化物）として、ダイ オキシン類生成を促進させるものと考えられる。また、こ れは、炭素構造のエッジの塩素化 $(\mathrm{C}-\mathrm{Cl}$ bond の形成) の 促進のほか、部分酸化反応による前駆物質の生成促進とも 強い関係がある。

炭素マクロ構造の酸化は、arm chair 面と zig-zag 面から 成るエッジ部と呼ばれる部分で優先的に進行する。特に de novo 合成反応が進行する低温での部分酸化反応は、主とし て zig-zag 面で進行すると考えられる。これには、共存する 金属化合物が大きな影響を及ぼす。Mulらは、様々な金属 の酸化物、塩化物、酸塩化物が「すす」の酸化反応に及ぼ す影響を報告している ${ }^{15)}$ 。反応速度上昇効果の大きさの程 度から、各金属を以下の 3 グループに分類した。

(1) $\mathrm{Cu} 、 \mathrm{~Pb}$

酸塩化物 $>$ 塩化物 $>$ 酸化物

(2) Fe、Mo、Bi

酸塩化物 $\doteqdot$ 塩化物 $>$ 酸化物

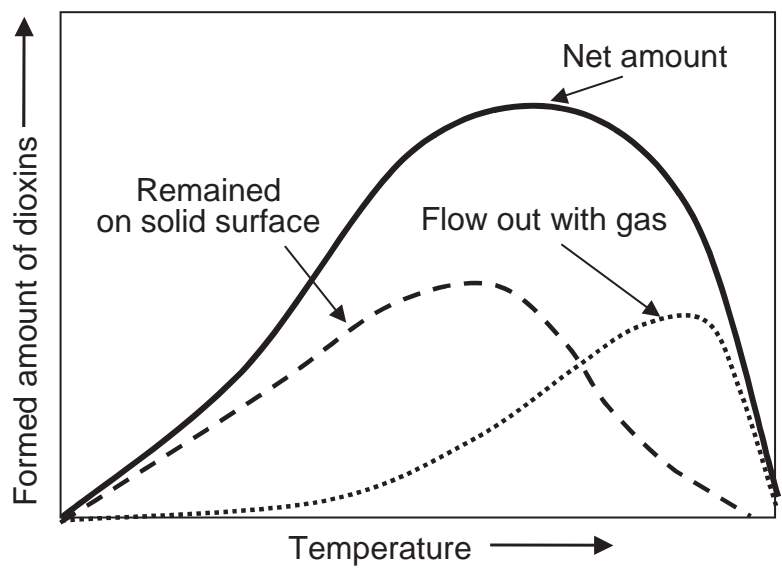

Fig. 6. An image on the formation behavior of dioxins during de novoexperiments.

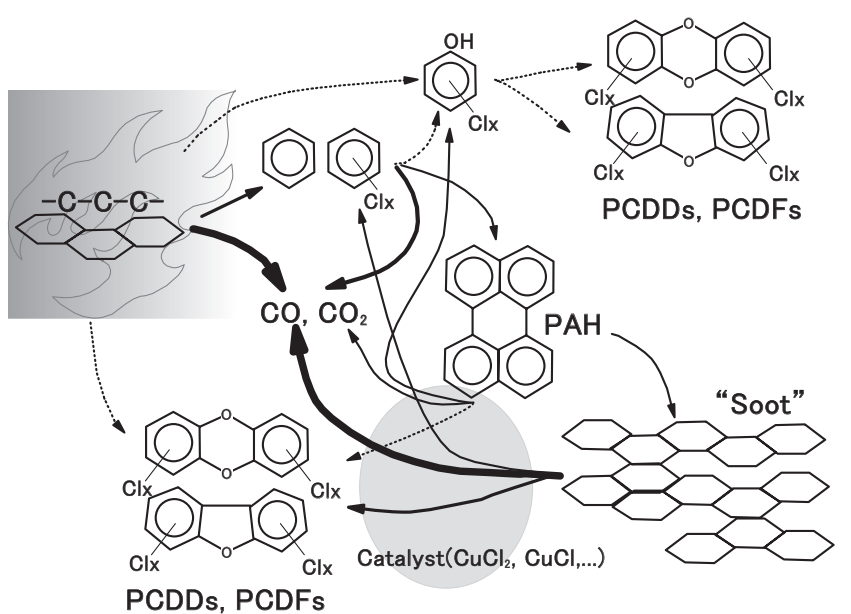

Fig. 7. Formation route of dioxins in the combustion process proposed by Takeuchi1 ${ }^{4}$.

(3) $\mathrm{Co} 、 \mathrm{Ni} 、 \mathrm{Ca}$ 塩化物 $>$ 酸化物

酸塩化物を形成しやすい $\mathrm{Cu}$ や $\mathrm{Pb}$ は、自身の酸化還元 (redox) サイクルの他、Fig. 8 に示すような機構により、 炭素表面へ活性な酸素を供給して、炭素の酸化反応を促進 する効果を持つ。第 1 は炭素による金属化合物の還元、第 2 は雲囲気中酸素による金属の酸化であり、このサイクル の繰り返しにより反応が進行するものと考えられる。また、 $\mathrm{PbCl}_{2} 、 \mathrm{CuCl}_{2} 、 \mathrm{CuCl}$ などの一部の金属塩化物は、対象温度 で比較的大きな飽和蒸気圧を示す。したがって、気相を通 じた反応面への移動が容易であり、反応促進効果が持続す ることが指摘できる。

以上のように、 de novo 合成反応によるダイオキシン類生 成には気相中の酸素の存在が不可欠であることが従来から 良く知られている ${ }^{16}$ 。水蒸気もダイオキシン類の生成・分 


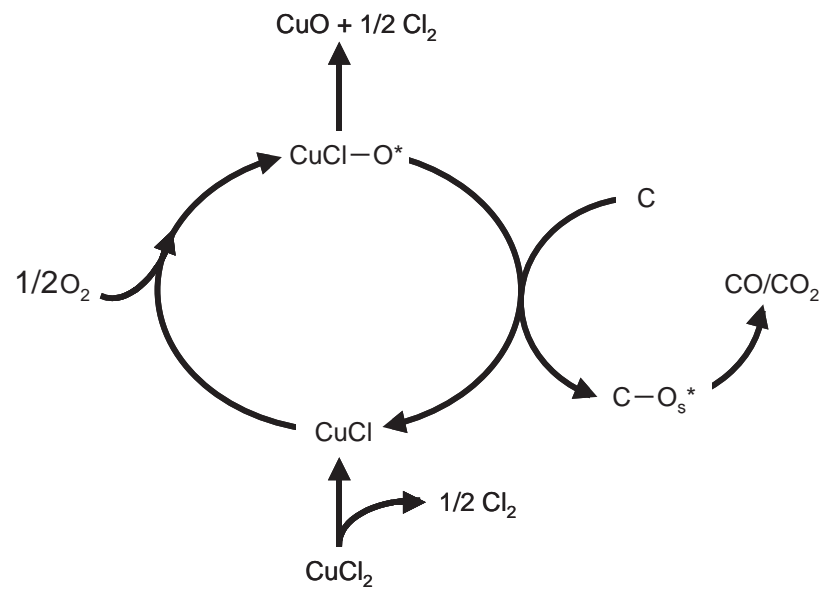

Fig. 8. The scheme for the catalysis mechanism of $\mathrm{CuCl} 2$ in soot oxidation $^{15)}$.

解に関与し、塩素化触媒の不活化と共に水素ポテンシャル の上昇などによりダイオキシン類の脱塩素化を進める可能 性がある。硫黄も金属触媒を硫酸化するポテンシャルを持 つため、ダイオキシン類発生を抑制する物質に分類される。 実際、系内に多量に硫黄が存在する硫化鉱を原料とした非 鉄製錬プロセスでは、ダイオキシン類発生が問題になって いない。

アンモニアや尿素、アミンなど有機窒素化合物もダイオ キシン類生成反応抑制物質として注目されてきた。そのメ カニズムとして、 $\mathrm{NH}_{3} \mathrm{Cl}$ の生成による系内の塩素ポテンシ アル低減効果や、銅など金属触媒との錯体形成による不活 性化が考えられてきたが、筆者らはこれらから発生する活 性な窒素による炭素構造のエッジの窒素化や前駆物質の炭 素の窒素化 $(\mathrm{C}-\mathrm{N}$ bond の形成）に起因するものと考えて いる ${ }^{17)} 。 こ の$ 効果を確認するために、廃棄物焼却炉の高温 排ガス冷却塔噴霧水に尿素を添加する試験を行い、最終排 ガス中の毒性濃度が低下することを確認した。Fig. 9 に結 果の一例を示す。冷却噴霧水中の尿素濃度が 1000 および $2000 \mathrm{ppm}$ の場合、尿素無添加に比較してそれぞれ $41 \%$ お よび 46\%低下している ${ }^{18)}$ 。

\section{5. 鉄鋼プロセスにおけるダイオキシン類排出抑制}

\section{1）製鋼用電気炉}

ビルや自動車などの解体、使用済みスチール缶などの回 収による市中回収スクラップには、塩素を含有するプラス チック類などが混入している。スクラップ中の塩素濃度低 下はダイオキシン類の発生抑制に顕著な効果がある。しか し、塩化ビニルなどの除去は技術的に難しい状況であり、 やはり、排ガス処理が重要になる。具体的には、高温かつ 安定な 2 次燃焼や建屋内の集塵ガスとの混合による急冷、 バグハウス入口温度の低下などである。

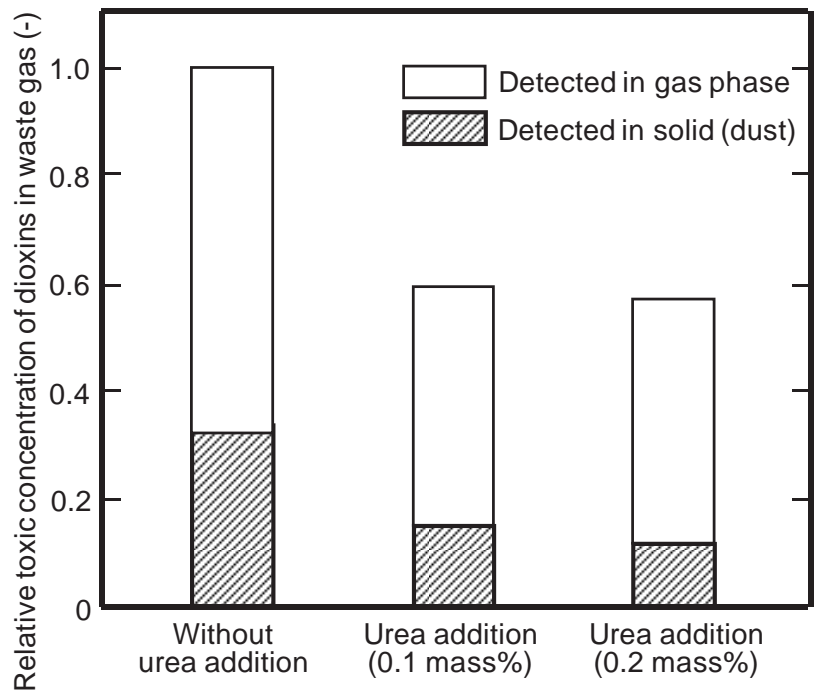

Fig. 9. Effect of urea addition to the splayed water of cooling tower of a solid waste incinerator on the toxic concentration of dioxin in the waste gas $^{18)}$.

2）鉄鉱石焼結プロセス

やはり、原料中塩素濃度とダイオキシン類生成量に正の 相関関係があるため、その低下が望ましい。前述したよう に、焼結プロセスは粉状鉄鉱石を高炉用鉄源として塊成化 する他に、製鉄所内のダスト、スラッジ、ミルスケールな どを鉄源としてリサイクルする役割を持つ。特に焼結プロ セス自身の排ガス集塵ダストをリサイクルする場合、集塵 を強化すれば塩素成分もリサイクルされて、工程内を濃縮 循環することになる。したがって、ダスト類の水洗、およ びロータリーキルンや回転炉床炉を用いる高温還元に伴う 脱塩素は、系内から塩素成分を除去するために効果的であ る。また、排ガス中ダイオキシン類の最終的な除去のため に、主要製鉄所の焼結機には NOx の低減効果も期待できる 活性コークス吸着塔を設置するのが主流になっている ${ }^{19) 。 ~}$

\section{6. おわりに}

以上、高温プロセスにおけるダイオキシン類発生に関す るこれまでの研究について解説した。我が国のダイオキシ ン類排出量はここ数年で顕著に削減されており、ダイオキ シン類対策特別措置法を主体とした政策の成果と考えられ る。そこには、新しい技術を開発、適用し、的確に操業す る自治体や企業の努力と共に、関連現象を理解して制御す るための基礎的な研究、開発が貢献しているのは論を待た ない。一方、POPs 条約が発効したことにより、PCBs や ヘキサクロロベンゼンなど、ダイオキシン類以外の新たな 有機塩素化合物の発生と抑制に関する情報が求められるよ うになってきている。以上、本稿が高温プロセスにおける 総合的な有機污染物質の排出抑制にむけた検討の端緒とし て、読者の考えの整理の一助となれば幸いである。 


\section{文 献}

1) 武田邦彦：“環境問題はなぜウソがまかり通るのか”、 洋泉社, (2007)

2) D. T. Nakahata and J. A. Mulholland: Proc. Combust. Inst., 28(2000), 2701-2707

3) F. Iino, T. Imagawa, M. Takeuchi, M. Sadakata, Environ. Sci. \& Technol., 33(1999), 1038-1045

4) N. W. Tame, B. Z. Dlugogorski and E. Kennedy: Environ. Sci. Technol. 41(2007), 6425-6432

5) N. W. Tame, B. Z. Dlugogorski and E. M. Kennedy: Progress in Energy and Combustion Science, 33(2007), 384-408

6) L. Stieglitz, G. Zwick, J. Beck, W. Roth and H. Vogg: Chemosphere, 18(1989), 1219-1226

7) G. Laue and R. Herzschuh: Organohalogen Compounds, 31(1997), 542-545
8) S. Kuzuhara, H. Sato, E. Kasai and T. Nakamura: Environ. Sci. \& Technol., 37(2003), 2431-2435

9) E. R. Altwicker: Sci. Total Environ., 104 (1991), 47-72

10) B. K. Gullett, K. R. Bruce and L.O. Beach: Environ. Sci. Technol., 26(1992) 1938-1943

11) J. G.P. Born, P. Mulder and R. Louw: Environ. Sci. Technol., 27(1993), 1847-1863

12) M. S. Milligan and E.R. Altwicker: Environ. Sci. Technol., 30(1996), 225-229

13) K. Shin and Y. Chang: Chemosphere, 38(1999), 2655-2666

14) 竹内正雄 : 化学工学, 64(2000), 121-127

15) G. Mul, F. Kapteijn and J. A. Moulijn: Applied Catalysis B: Environmental, 12(1997), 33-40

16) M. S. Milligan and E. Altwicker: Carbon, 31(1993), 977-984

17) S. Kuzuhara, H. Sato, N. Tsubouchi, Y. Otsuka and E. Kasai: Environmental Science \& Technology, 39(2005), 795-799

18) E. Kasai, S. Kuzuhara and H. Goto: ISIJ Int., submitted

19) A. Umezu, H. Kusunoki, S. Kabuto, M. Hamada and K. Takatani, CAMP-ISIJ, 13(2000), 807 